\title{
Laboratory development of Capitella sp. A (Annelida: Capitellidae) from a NW Mediterranean fish farm reared under different organic enrichment conditions
}

\author{
Nuria Méndez \\ Unidad Académica Mazatlán. Instituto de Ciencias del Mar y Limnología, Universidad Nacional Autónoma de México \\ P.O. Box 811, Mazatlán 82000, Sinaloa, México. E-mail: nuri@ola.icmyl.unam.mx
}

\begin{abstract}
Summary: The polychaete Capitella sp. A, collected in a NW Mediterranean fish farm (Les Cases d'Alcanar, Tarragona, Spain), was cultured for the first time under experimental conditions with different organically enriched sediments to study the differences in development and growth. The species proved to be dioecious and had lecithotrophic development. Sizes of individuals and duration of the developmental stages varied widely, as in most known species of Capitella. In organically enriched sediments, the juveniles were seen one day after hatching and immature females (i.e. with yellow ovaries) after 52 days. Females may reach maturity (i.e. show white intra-coelomic oocytes) at about 64 days old, and the species had a life span of 167 days. According to its development, Capitella sp. A differs from all known lecithotrophic species of the genus. The results also proved that organically enrichment enhanced growth and survival, whereas lowering food can cause morphological alterations such as reduced size in male genital spines.
\end{abstract}

Keywords: polychaete; Capitella capitate; development; reproduction; organic enrichment; sibling species.

Desarrollo en laboratorio de Capitella sp. A (Annelida: Capitellidae) de una piscifactoría del Mediterráneo NO cultivado en diferentes condiciones de enriquecimiento orgánico

Resumen: El poliqueto Capitella sp. A, procedente de una piscifactoría del Mediterráneo NO (Les Cases d'Alcanar, Tarragona, España), se cultivó por primera vez en condiciones experimentales en sedimentos con diferente contenido orgánico con el fin de estudiar su desarrollo y crecimiento. La especie resultó ser dioica, con desarrollo lecitotrófico. El tamaño de los individuos y la duración de las etapas del desarrollo variaron ampliamente, como ocurre en la mayoría de especies conocidas del género. En el sedimento con enriquecimiento orgánico se observaron juveniles un día después de la eclosión y hembras inmaduras (con ovarios amarillos) al cabo de 52 días. La aparición de oocitos intracelómicos blancos permitió estimar la edad de maduración de las hembras en unos 64 días, mientras que los adultos sobrevivieron durante 167 días. En función de su desarrollo, Capitella sp. A difiere de todas las especies lecitotróficas de Capitella conocidas. Estos resultados también demuestran que el enriquecimiento orgánico mejora el crecimiento y la supervivencia, mientras que una escasez de alimento puede provocar alteraciones morfológicas tales como la reducción en el tamaño de las espinas genitales de los machos.

Palabras clave: poliqueto; Capitella capitata; desarrollo; reproducción; enriquecimiento orgánico; especies gemelas.

Citation/Como citar este artículo: Méndez, N. 2016. Laboratory development of Capitella sp. A (Annelida: Capitellidae) from a NW Mediterranean fish farm reared under different organic enrichment conditions. Sci. Mar. 80(4): 535-542. doi: http://dx.doi.org/10.3989/scimar.04450.08B

Editor: D. Martin.

Received: April 1, 2016. Accepted: October 17, 2016. Published: November 9, 2016.

Copyright: () 2016 CSIC. This is an open-access article distributed under the terms of the Creative Commons Attribution (CC-by) Spain 3.0 License.

\section{INTRODUCTION}

The Capitella capitata (Fabricius, 1780) speciescomplex (Annelida: Capitellidae) consists of at least 50 non-interbreeding but morphologically similar sibling species. Among them, about 13 have been described from laboratory cultures (Blake et al. 2009). The $C$. capitata sibling species have been distinguished based on allozyme and general protein patterns, ecophysiological characteristics and reproductive modes, but also using genes and, ultimately, classical morphological characters. However, despite the high num- 
ber of species within the complex, only a few have been described in detail. Among them are Capitella sp. I, Capitella sp. Ia, Capitella sp. II, Capitella sp. III and Capitella sp. IIIa (Grassle and Grassle 1976, Eckelbarger and Grassle 1983); Capitella sp. I, Capitella sp. II and Capitella cf capitata (Wu et al. 1991); Capitella sp. I (Petraitis 1985); Capitella sp. (George 1984); Capitella Types 1 and 2 (Pearson and Pearson 1991); and Capitella sp. I (recently re-named C. teleta by Blake et al. 2009). Developmental modes (i.e. planktotrophic, lecithotrophic or direct development, poecilogony, hermaphroditism, size and duration of the stages, number of brooded embryos, ciliation in metatrochophores) have been used to distinguish some species of the complex, which were then named according to their size or to the collection locality. Among them are Capitella sp. S (small) and Capitella sp. L (large) (Gamenick 1997); Capitella sp. M, from Milos in Greece (Gamenick et al. 1998); Capitella sp. K, from the Kilmelford salmon farm in Scotland; Capitella sp. $\mathrm{Cm}$ and Capitella sp. Ct, from the Cranford salmon farm in Ireland (Méndez et al. 2000); Capitella sp. B, from Barcelona in Spain (Méndez 2002); Capitella sp. Y, from Estero del Yugo in Mazatlán, Mexico (Méndez 2006); Capitella sp. G, from Galveston in Texas, USA (Adkins and Schulze 2011); and Capitella sp. A, from the fish farm Les Cases d'Alcanar, Tarragona, Spain (Méndez and Barata 2015).

The $C$. capitata complex mostly includes opportunistic species showing the classical r-strategy that are considered as worldwide indicators of anthropogenic organic pollution in marine sediments (e.g. Pearson and Rosenberg 1978, Méndez et al. 1997, 1998). They also dominate the assemblages inhabiting organically enriched sediments around fish farms, where they reach extremely high densities (e.g. Brown et al. 1987, Tsutsumi 1987, Méndez et al. 2000).

Although the species of the complex are known to reproduce through benthic (lecithotrophic) and free-swimming (planktotrophic) larvae mainly in experimental conditions, detailed data on the lifespan are scarce and differ widely according to the individual species and their geographic origin (Méndez et al. 2000). In turn, field and laboratory studies have demonstrated that growth rates strongly depend on food availability (Tenore 1977, Forbes and Lopez 1990, Tsutsumi et al. 1990), while lowering food can provoke both larval and juvenile mortality (Qian and Chia 1994, Méndez 2002).

Females of Capitella often construct brooding tubes (open along both sides) with faecal materials, substratum and potential food. Fertilization occurs either internally or during spawning (Reish 1980). The eggs are placed around the inner tube surface, where they remain until they develop into trochophores (Tsutsumi and Kikuchi 1984). Females irrigate the brooding tubes by periodic body undulations and the trochophores have two small eyes and two ciliary rings that allow them to move freely inside the tube and then swim in the water column (Reish 1980). Larvae may reach the metatrochophore stage either inside the tube or in the water column. Metatrochophores have $13 \mathrm{seg}$ - ments and a visible ventral stomodeal concavity that is not connected with the gut (George 1984). They are lecithotrophic and thus feed on their own yolk reserves (Hermans 1979). Some species of the complex may have two well-defined ciliary rings allowing them to swim (George 1984, Méndez 2002, 2006), while other species lack such rings (Warren 1976a, Méndez 1995). However, their chaetal arrangement always consists of capillaries in the first three setigers and hooded hooks in the subsequent ones (Méndez 1995).

Metatrochophores become juveniles after settlement, generally outside the brooding tube. Juveniles are completely vermiform, have a chaetal arrangement identical to that of metatrochophores, and the complete segmentation and the distinction between the thorax and abdomen are clear (Méndez 1995). As they grow, the thoracic hooded hooks are gradually replaced by capillaries until the maximum of seven chaetigers with capillaries typical in adults (Warren 1976b).

Individuals are considered to be adults, albeit immature, when showing an elongated prostomium (with or without eyes) and at least five capillary thoracic chaetigers. At this stage, females contain yellowish ovaries in the mid-ventral region. Males are mature when they bear genital spines between the $8^{\text {th }}$ and $9^{\text {th }}$ setigers and females when they have free-floating, white, intracoelomic oocytes (Reish 1980, Méndez 2002). When they get older, there is an evident change of colour, from intense red to greyish red (Méndez 2006).

The present study deals with one of the Mediterranean fish farm species of the complex, Capitella sp. A. The reproduction and development of the species is known to be affected by the antidepressant fluoxetine commonly known as Prozac (Méndez and Barata 2015). However, there are some lags in the knowledge of its development patterns, because a key aspect in the experimental design and interpretation of the environmental stress effects both individual and population levels. This study is therefore the first description of the reproductive mode and development of Capitella sp. A under different organic enrichment conditions, as well as an attempt to determine whether this information may be used to assess its status within the species complex.

\section{MATERIALS AND METHODS}

Specimens of Capitella sp. A were collected in June 2012 in a sea bass and goldfish fish farm at Les Cases d'Alcanar, Tarragona (NW Mediterranean coast of Spain), located $2500 \mathrm{~m}$ offshore $\left(40^{\circ} 32^{\prime} 38^{\prime \prime} \mathrm{N}\right.$, $\left.0^{\circ} 33^{\prime} 38^{\prime \prime} \mathrm{E}\right)$. The $15 \mathrm{~cm}$ superficial layer of the sediments were collected under the fish cages by SCUBA diving at 12-13 m depth and kept in a container. Sediment was sieved through a $0.5 \mathrm{~mm}$ mesh and the retained worms were collected with forceps and placed in a flask with seawater. The sediment consisted mainly of mud with mussel remains, and the organic matter content was of $7.76 \pm 0.66 \%(n=2)$. The accompanying fauna consisted of a few individuals of other capitellids, as well as some Nereididae, Chaetopteridae and Lumbrineridae, and isopods. 
The Capitella sp. A specimens were maintained in stock cultures under laboratory conditions at the Department of Environmental Chemistry, Institute of Environmental Assessment and Water Research (CSIC, Barcelona). The rearing tanks $(20 \times 12 \mathrm{~cm})$ contained $400 \mathrm{~g}$ (dry weight) of clean sediment, namely the experimental sediment, from the beach of Vallcarca, Sitges (NE Spain), which had previously been dried $\left(60^{\circ} \mathrm{C}\right)$ and sieved to a grain size lower than $250 \mu \mathrm{m}$ in diameter and frozen. Each tank also contained $1.5 \mathrm{~L}$ of filtered $(<30 \mu \mathrm{m})$ aerated seawater (salinity $36 \mathrm{psu}$ ), namely the experimental seawater, and was maintained at $20 \pm 1^{\circ} \mathrm{C}$ in the dark. Animals were fed by adding 0.5 $\mathrm{g}$ of artificial food per culture weekly. Artificial food consisted of a mixture of equal parts of commercial fish food (Wardley*), baby cereal (Milupa) and dried spinach (Méndez and Barata 2015). The food items were dried, ground and sieved to less than $250 \mu \mathrm{m}$. The specimens were reared under these conditions for one month prior to the experiments.

To assess the development of Capitella sp A, two series of experiments with two different organic enrichment treatments were conducted. In the first series, the timing and size of life stages from spawning until immature adults were followed. In the second series, the growth of immature adults of unknown age collected directly from the stock cultures was followed. Results from the two series were pooled to complete the picture of the species lifespan.

\section{Experimental series 1. Duration, size and development of early stages}

Mature females (with white coelomic oocytes) and males (bearing genital spines) were sorted from the stock cultures. Ten couples ( 5 in each treatment) were placed in dishes containing $0.5 \mathrm{~g}$ of experimental sediment with different organic matter contents (see details below) and $7 \mathrm{~mL}$ of experimental seawater, and were maintained at $20 \pm 1^{\circ} \mathrm{C}$ in the dark. The couples were observed daily under a dissecting microscope (Nikon SMZ1500, mod. C-DSD230) until fertilization and brooding tube building, and then also during brood development and until hatching. After hatching, females and males were removed and larvae were maintained in the same dishes to avoid damage and transport losses. Larvae were observed and measured daily, young juveniles every 2-3 days, and old juveniles and adults every 6-7 days. The duration of developmental stages was recorded for each brood. Experimental sediment and seawater were replaced weekly.

For size measurements, specimens were photographed with a camera (Nikon Digital Sight DS-R1) connected to the dissecting microscope. From each picture, body length (from prostomium to pygidium) and area (based on the contour of entire worms) were calculated using the image analysis software NISElements AR 3.0. S16, Nikon (Laboratory imaging, 1991e2008). Body volume $\left(\mathrm{V} \mathrm{mm} \mathrm{mm}^{3}\right)$ was calculated assuming a cylindrical shape (Forbes et al. 1994) as $V=\pi A^{2} / 4 L$, where $A$ is the area and $L$ the length of the worm.
Brooding larvae were measured inside the brood by transparency when possible (only larvae located in the tube sections not covered by mud). The number of individuals within a brood varied from 5 to 15 . Metatrochophores and juveniles were measured to estimate the average brood volume. To increase the accuracy in adult measurements, three observations were performed and averaged to obtain the volume of each given individual.

Growth rates $\left(\mathrm{mm}^{3}\right.$ day $\left.^{-1}\right)$ were calculated as differences in volume between one census day and the subsequent one, divided by the number of days elapsed between measurements, and a global estimate was derived from the mean volumes calculated for each brood analysed.

In this experimental series, two organic enrichment treatments were tested. Animals for both treatments were kept under the same conditions (including the respective addition of artificial food) from coupling, during hatching and until death. Moreover, as lecithotrophic larvae do not feed, it was assumed that larval growth was independent of the organic enrichment treatments.

a) "Organically enriched". The sediment was obtained from Els Alfacs Bay, one of the bays from the Ebro Delta facing Les Cases d'Alcanar. The organic content was $8.23 \pm 0.16 \%(n=3)$ and it was sieved through a $250 \mu \mathrm{m}$ pore size mesh. An amount of 0.001 $\mathrm{g}$ (dry weight) of artificial food was added weekly to each dish (Méndez 2002) until the worms became juveniles. Growth was recorded for larvae and juveniles of broods 3, 4 and 5 and the treatment lasted until the worms' death (79 days).

b) "Natural sediment". This treatment used experimental sediment (organic content of $1.57 \pm 0.013 \%$, $\mathrm{n}=3$ ). Growth was recorded for individuals of broods 1 and 2, and the treatment lasted until the worms' death (22 days).

\section{Experimental series 2. Adult size and development}

Prior to the experiments, two stock cultures of worms were reared in aquarium tanks $(8 \times 17 \mathrm{~cm})$ with $100 \mathrm{~g}$ (dry weight) of sediments from Els Alfacs Bay and Vallcarca, respectively (treated as the experimental sediment) and $1 \mathrm{~L}$ of aerated experimental seawater, maintained at $20 \pm 1^{\circ} \mathrm{C}$ in the dark. Artificial food $(0.5 \mathrm{~g}$ per culture) was added weekly, with different components in the two cultures (see below for details). After one month, 0.5-g portions of sediment from each stock culture were frozen until they were used in the experimental treatments and the worms were transferred to 6-cm-diameter dishes for growth analyses. The worms' volume was calculated as in Experimental series 1.

For the experimental treatments, immature adults in different developmental stages (but at least initially boring five thoracic chaetigers with capillaries) were sorted and placed individually in dishes. Development stages were identified by the number of thoracic setigers bearing capillaries (five to seven chaetigers), by the presence of white or yellow coelomic oocytes (females) and genital spines (males) and by the grey col- 
Table 1. - Duration and size of the observed developmental stages of Capitella sp A during experimental series 1.

\begin{tabular}{|c|c|c|c|c|c|}
\hline Developmental stages & Volume range $\left(\mathrm{mm}^{3}\right)$ & Mean \pm SD $\left(\mathrm{mm}^{3}\right)$ & Age (days) & $\mathrm{N}$ & Number of broods \\
\hline \multicolumn{6}{|l|}{ Treatment 1a) Organically enriched } \\
\hline Females after hatching (1st generation) & $1.043-4.376$ & $2.580 \pm 1.681$ & & 3 & 3 \\
\hline Metatrochophores inside broods & $0.003-0.005$ & $0.004 \pm 0.001$ & -1 & 9 & 1 \\
\hline Swimming metatrochophores & $0.003-0.006$ & $0.005 \pm 0.001$ & 1 to 3 & 26 & 3 \\
\hline Settling metatrochophores & 0.005 & $0.005 \pm 0.000$ & 3 to 4 & 10 & 1 \\
\hline Transparent juveniles & $0.009-0.016$ & $0.014 \pm 0.002$ & 2 to 13 & 135 & 3 \\
\hline 3 chaetigers with capillaries & $0.009-0.016$ & $0.014 \pm 0.002$ & 1 to 12 & 132 & 3 \\
\hline Yellowish juveniles & $0.007-0.021$ & $0.015 \pm 0.004$ & 7 to 30 & 142 & 3 \\
\hline 4 chaetigers with capillaries & $0.008-0.132$ & $0.021 \pm 0.028$ & 7 to 32 & 147 & 3 \\
\hline Pinky juveniles & $0.105-0.160$ & $0.132 \pm 0.039$ & 32 & 2 & 1 \\
\hline 5 chaetigers with capillaries & $0.457-0.596$ & $0.526 \pm 0.098$ & 37 to 52 & 11 & 1 \\
\hline Red adults & $0.457-1.378$ & $0.841 \pm 0.342$ & 37 to 79 & 29 & 1 \\
\hline 6 chaetigers with capillaries & $0.710-1.024$ & $0.867 \pm 0.221$ & 59 to 66 & 13 & 1 \\
\hline Yellow ovaries & $0.583-1.378$ & $0.967 \pm 0.322$ & 52 to 79 & 23 & 1 \\
\hline Lack of eyes & $0.583-1.378$ & $0.967 \pm 0.322$ & 52 to 79 & 23 & 1 \\
\hline 7 chaetigers with capillaries & $1.137-1.378$ & $1.258 \pm 0.171$ & 72 to 79 & 5 & 1 \\
\hline \multicolumn{6}{|l|}{ Treatment 1b) Natural sediment } \\
\hline Females after hatching (1st generation) & $2.262-5.735$ & $3.999 \pm 2.456$ & & 2 & 2 \\
\hline Swimming metatrochophores & $0.003-0.009$ & $0.006 \pm 0.003$ & 1 & 3 & 2 \\
\hline Transparent juveniles & $0.003-0.014$ & $0.010 \pm 0.004$ & 1 to 11 & 91 & 2 \\
\hline 3 chaetigers with capillaries & $0.003-0.014$ & $0.010 \pm 0.003$ & 1 to 15 & 122 & 2 \\
\hline Yellowish juveniles & $0.003-0.012$ & $0.008 \pm 0.004$ & 9 to 22 & 72 & 1 \\
\hline 4 chaetigers with capillaries & $0.003-0.007$ & $0.005 \pm 0.003$ & 19 to 22 & 27 & 1 \\
\hline
\end{tabular}

our typical of old specimens. Each dish contained 0.5 $\mathrm{g}$ of sediment from the respective stock cultures and 7 $\mathrm{mL}$ of experimental seawater, and was maintained at $20 \pm 1^{\circ} \mathrm{C}$ in the dark. Growth rates were estimated as in experimental series 1 , but the global estimate was derived from the mean volumes calculated for each measured individual.

In this experimental series, the two organic enrichment treatments were:

a) "Organically enriched". This treatment used sediment from the Els Alfacs Bay stock culture. The worms were fed with artificial food. The organic content was $7.3 \pm 0.26 \%$. The worms were observed and measured weekly, and the sediment and seawater were also replaced weekly. The duration of this treatment was 29 days.

b) "Non-organically enriched". This treatment used sediment from the Vallcarca stock culture. Worms were fed with artificial food without baby cereals. The organic content was $2.0 \pm 0.01 \%$. The worms were observed and measured every 10 days, and sediments and seawater were replaced in parallel. For logistic reasons, the worms were measured only on days 1 and 10; however, the experiment was kept until the worms' death (58 days) for developmental stage timing.

\section{RESULTS}

\section{Experimental series 1}

The duration of each developmental stage was highly variable (Table 1). Fertilization and brooding tube building occurred only in five couples out of the original ten (three in treatment $1 \mathrm{a}$ and two in $1 \mathrm{~b}$ ) between 6 and 20 days after the experimental onset. Body volumes of brooding females ranged from 1.04 to 5.74 $\mathrm{mm}^{3}\left(3.15 \pm 1.88 \mathrm{~mm}^{3}\right.$ on average; $\left.\mathrm{n}=5\right)$.

In both treatments, Capitella sp. A showed lecithotrophic development, as all hatched larvae were metatrochophores, and juveniles occurred one day after hatching. No mature adults were observed during the course of this experimental series. Sizes and timing differed between the two treatments. The juveniles from treatment 1a reached the stage with seven setigers bearing capillary chaetae and survived for 79 days, while those from treatment $1 \mathrm{~b}$ reached the yellowish stage, with only four chaetigers with capillaries, and survived only for 15 to 22 days, depending on the brood (Table 1).

In treatment 1a, ciliated metatrochophores hatched at day 1 and swam actively in the water column for about 3-4 days before settling. They swam close to the bottom, describing circular and slow movements. Swimming and settling metatrochophores, as well as juveniles, occurred simultaneously in the dishes (Table 1).

In all broods from the two treatments, juveniles were observed at day 1 . They were vermiform shape and had a complete segmentation, clear distinction between thorax and abdomen, two small eyes, at least three setigers with capillary chaetae, and transparent bodies. The number of thoracic chaetigers bearing capillaries increased with time from day 7, although this was generally delayed in worms from treatment $1 \mathrm{~b}$ (Table 1). Most juveniles remained transparent until day 13 and started to become yellowish from day 7 to 30. Only worms in treatment 1a developed until the pink stage (day 32), showing some haemoglobin spots, and became fully red due to haemoglobin production on day 37 (Table 1). Immature females with mid-body yellowish ovaries occurred on day 52; they also lacked eyes and had seven (notopodial) and six (neuropodial) chaetigers with capillaries (Table 1).

In treatment $1 \mathrm{a}$, brooding metatrochophores could be seen only in brood 5 (considered as day 0 in Fig. $1 B)$, measuring $0.004 \pm 0.005 \mathrm{~mm}^{3}(\mathrm{n}=10)$. Metatrochophore volume varied among broods (Fig. 1B) and larval growth could not be adjusted to any model. The mean growth rate was $0.000 \pm 0.003 \mathrm{~mm}^{3}$ day $^{-1}(\mathrm{n}=5)$. Juveniles from brood 3 had negative growth (Fig. 1C), which may have been responsible for the observed bias 
A

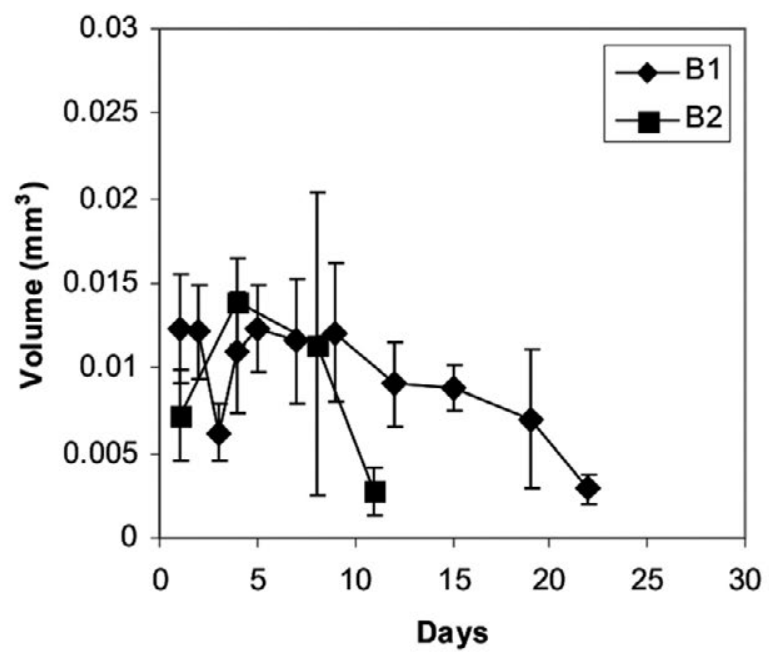

C

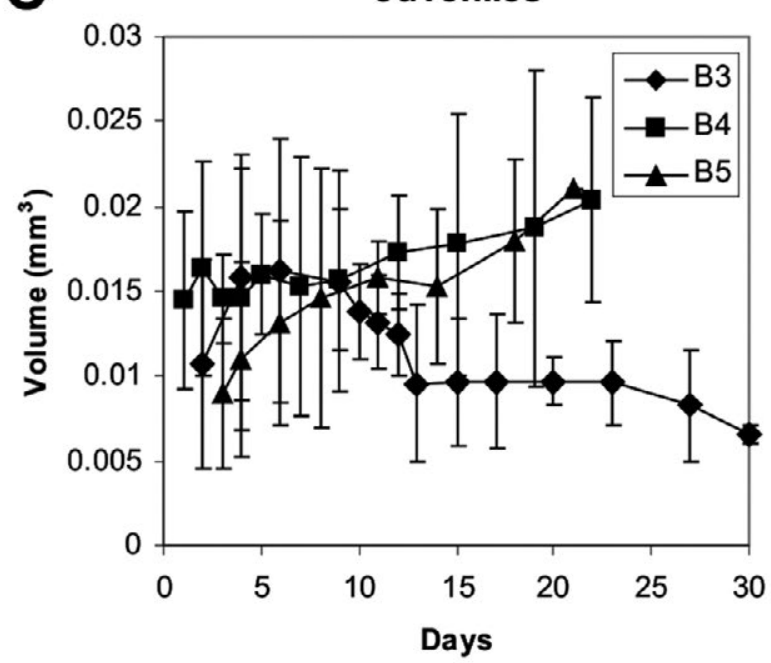

B

Metatrochophores

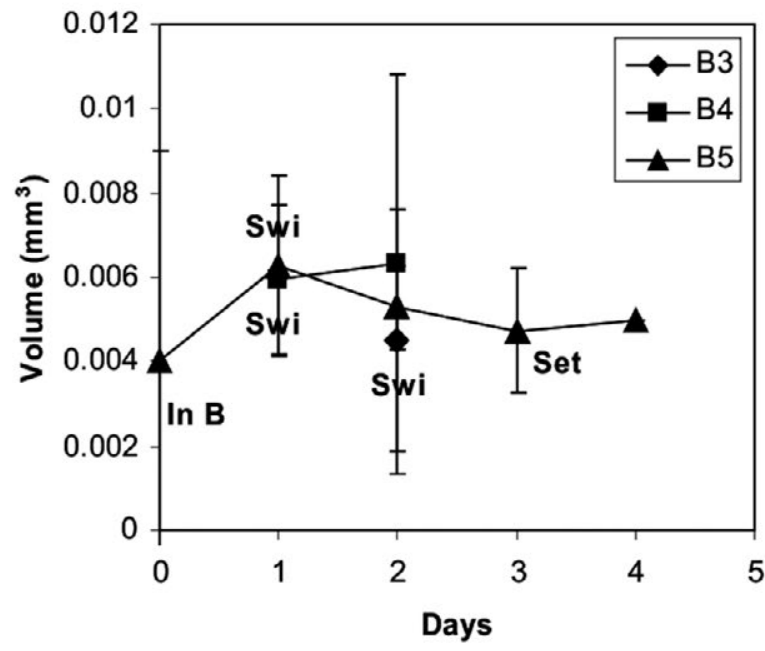

D Juveniles and immature adults

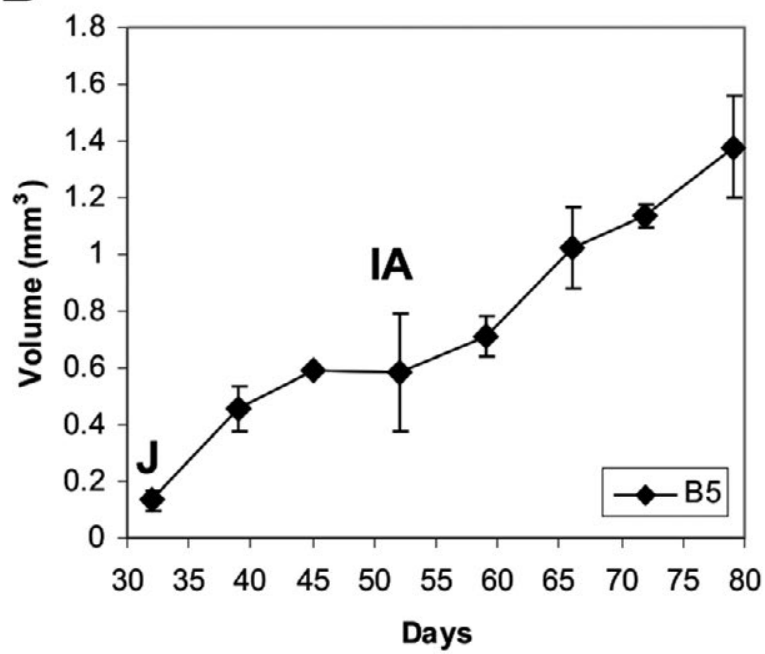

Fig. 1. - Average volume \pm SD of individuals of Capitella sp. A over time during the experimental series 1. A, juveniles reared in the "natural sediment" treatment $1 \mathrm{~b}$ (broods 1 and 2); B, metatrochophores in the "organically enriched sediment" treatment 1a (broods 3 to 5); C, juveniles in the "organically enriched sediment" treatment 1a (broods 3 to 5); D, juveniles and immature adults in the "organically enriched sediment" treatment 1a (brood 5) (In B, metatrochophores inside broods; Swi, swimming metatrochophores; Set, settling metatrochophores; J, juveniles; IA, immature adults).

toward low mean volumes (Table 1). Juveniles' growth in broods 4 and 5 could be adjusted to the power function volume $=0.0046 \mathrm{age}^{0.425}(\mathrm{r}=0.662 ; \mathrm{p}<0.001 ; \mathrm{n}=22)$, with mean growth rates of $0.005 \pm 0.011 \mathrm{~mm}^{3} \mathrm{day}^{-1}$ $(n=19)$. Growth of immature adults was described by the power function volume $=0.0001 \mathrm{age}^{2.1216}(\mathrm{r}=0.991$; $\mathrm{p}<0.001 ; \mathrm{n}=5)$, with mean growth rates of $0.029 \pm 0.011$ $\mathrm{mm}^{3}$ day $^{-1}(\mathrm{n}=4)$ (Fig. 1D).

In treatment $1 \mathrm{~b}$, juveniles' growth was negative (Fig. 1A) and followed the exponential function volume $=0.0122 \mathrm{e}^{-0.0441 \text { age }}(\mathrm{r}=0.565 ; \mathrm{n}=15 ; \mathrm{p}<0.005)$, with mean growth rates of $0.000 \pm 0.003 \mathrm{~mm}^{3}$ day $^{-1}$ $(n=12)$. However, the few data available did not allow larval growth to be estimated.

\section{Experimental series 2}

Volume measurements of worms periodically observed in the treatments of experimental series 2 were highly variable (Table 2 ). In treatment $2 \mathrm{a}$, no males or old individuals were observed and female sexual structures occurred in almost all individuals. Mortality was not observed. Growth rates varied between -0.26 and $0.06 \mathrm{~mm}^{3} \mathrm{day}^{-1}$ (mean $-0.03 \pm 0.09 \mathrm{~mm}^{3}$ day $\left.^{-1} ; n=24\right)$. New adults from the treatment 2 a stock culture were selected and their known stages were also measured. These worms had evident sexual characters and included an immature female with yellow ovaries $\left(2.87 \pm 0.23 \mathrm{~mm}^{3}\right)$, a female with white coelomic oocytes $\left(7.33 \pm 0.36 \mathrm{~mm}^{3}\right)$, a red-grey old female $\left(3.23 \pm 0.01 \mathrm{~mm}^{3}\right)$, a very old grey female $(2.15 \pm 0.13$ $\left.\mathrm{mm}^{3}\right)$, and two males $\left(4.24 \pm 0.23\right.$ and $\left.2.89 \pm 0.07 \mathrm{~mm}^{3}\right)$.

In treatment $2 \mathrm{~b}$, both the worm's volume and the duration of their developmental stages varied widely (Table 2). The time from the first appearance of the stage with seven chaetigers with capillaries to the development of white coelomic oocytes ranged between 11 and 57 days (about 53 days on average after the pres- 
Table 2. - Volumes of immature adults selected from the stock cultures of the experimental series 2 and time elapsed from the stage of five chaetigers with capillaries.

\begin{tabular}{|c|c|c|c|c|}
\hline Developmental stages & Volume range $\left(\mathrm{mm}^{3}\right)$ & Mean \pm SD $\left(\mathrm{mm}^{3}\right)$ & $\mathrm{N}$ & Time (days) \\
\hline \multicolumn{5}{|l|}{ Treatment 2a Organically enriched } \\
\hline 5 chaetigers with capillaries & $0.887-4.591$ & $2.209 \pm 1.437$ & 6 & \\
\hline Yellow ovaries & $0.694-1.395$ & $1.044 \pm 0.496$ & 2 & $8-22$ \\
\hline White coelomic oocytes & $0.889-2.229$ & $1.416 \pm 0.715$ & 3 & $8-29$ \\
\hline \multicolumn{5}{|c|}{ Treatment $2 \mathrm{~b}$ Non-organically enriched } \\
\hline 5 chaetigers with capillaries & $0.393-0.933$ & $0.601 \pm 0.291$ & 3 & \\
\hline 6 chaetigers with capillaries & $0.207-3.442$ & $1.616 \pm 1.403$ & 5 & $9-12$ \\
\hline 7 chaetigers with capillaries & $0.387-3.551$ & $1.557 \pm 0.717$ & 21 & $18-24$ \\
\hline Yellow ovaries & $0.207-3.442$ & $1.342 \pm 0.901$ & 14 & $6-32$ \\
\hline White coelomic oocytes & - & - & - & about 53 \\
\hline Genital spines & - & - & - & about 25 \\
\hline
\end{tabular}

ence of specimens with five chaetigers with capillaries). The first observations of specimens having seven setigers with capillaries was most often simultaneous to that of genital spines, but sometimes the former appeared 12 days before (about 25 days on average after the presence of specimens with five chaetigers with capillaries). The change from intense red to greyish red specimens began to be evident from 23 to 58 days after the presence of seven setigers with capillaries (about 60 days on average after the presence of specimens with five chaetigers with capillaries).

During treatment $2 \mathrm{~b}$, only three males bearing 7 of 18 chaetigers with capillaries were observed, of which only two could be measured: one of them measured $5.42 \pm 0.31 \mathrm{~mm}^{3}$ after being selected from the stock culture, but was reduced to $3.39 \pm 0.11 \mathrm{~mm}^{3}$ ten days after the start of the experiment. The other one measured $2.31 \pm 0.14 \mathrm{~mm}^{3}$ after ten days. The genital spines of these three males were smaller than those of males from the stock cultures of treatment $2 \mathrm{a}$.

Growth rates ranged between -0.03 and -0.23 $\mathrm{mm}^{3}$ day $^{-1}\left(-0.08 \pm 0.05 \mathrm{~mm}^{3}\right.$ day $^{-1}$, on average; $\left.\mathrm{n}=18\right)$. Death occurred 10 to 88 days after the first observation of specimens with seven chaetigers with capillaries.

\section{DISCUSSION}

The reproductive strategies of the $C$. capitata species complex vary widely among sibling species and geographical regions (Méndez et al. 2000). Capitella sp. A was revealed to be a dioecious species with lecithotrophic development and shows a wide variability in size and in duration of the different developmental stages, as previously reported for other species of the complex (Méndez et al. 2000, Méndez 2002, 2006). Experimental series 1 demonstrated that juveniles already occurred one day after hatching, while immature females with yellow ovaries occurred at 52 days. The combination of results obtained in treatments $1 \mathrm{a}$ and 2a (i.e. organically enriched) show that it took 45 days (on average) to attain the five chaetigers with capillaries stage and 19 days from the specimens with five chaetigers with capillaries to those with white intracoelomic oocytes, so age at maturity was estimated to be approximately 64 days.

Lecithotrophic development is common among the worldwide species of the Capitella complex (Méndez et al. 2000, Méndez 2002, 2006). Benthic larvae are advantageous when local resources are abundant (Pear- son and Pearson 1991) and retention of larvae inside the brood tubes can favour the rapid build-up of a population in situations where food supply is not limiting and dispersal to new areas is therefore not essential (George 1984). Accordingly, a poor dispersal ability of benthic larvae allowing it to proliferate in small areas such as a fish farm seems to be a good strategy to enhance survival of the local population.

These results are consistent with the known data on the life history of the $C$. capitata species complex. Capitella sp. A clearly differs from all other lecithotrophic species around the world (Table 3). Despite the lack of molecular analyses, the results presented here based on the developmental characteristics and on some morphologic characters strongly support the hypothesis that Capitella sp. A has not been formally described to date. Moreover, though previous studies demonstrate that Capitella sp. I (Petraitis 1985, Pechenik and Cerulli 1991 and Blake et al. 2009, as C. teleta, among others), Capitella sp. IIIa (Grassle and Grassle 1976, Eckelbarger and Grassle 1983) and Capitella sp. Y (Méndez 2006) have lecithotrophic development, they can certainly be discarded as close relatives of Capitella sp. A because they are hermaphrodites.

The length of brooding females of Capitella sp. A, 11.1 to $15.6 \mathrm{~mm}(12.94 \pm 1.81 \mathrm{~mm}$ on average; $\mathrm{n}=5)$, attained the same order of magnitude as in Capitella Type 1 from West Scotland (from 8 to $25 \mathrm{~mm}$; Pearson and Pearson 1991). However, the metatrochophore lengths differ considerably: 0.39 to $0.56 \mathrm{~mm}(0.44 \pm 0.07 \mathrm{~mm}$ on average) vs. 1.14 to $3.45 \mathrm{~mm}$, respectively. Moreover, our species can also be distinguished from Capitella sp. from Vancouver, Canada (Quian and Chia 1992) by the duration of the metatrochophore stage, 1-4 days vs. ca. $24 \mathrm{~h}$, respectively.

Capitella cf. capitata has a life cycle of 9 months at Elba Island, Italy (Lardicci and Ceccherelli 1994), and C. capitata from Plymouth, England, has a life span of one year (Warren 1976a). In contrast, the maximum survival time of Capitella sp. A was estimated as 167 days (maximum 79 days to reach the seven setigers with capillary chaetae in treatment 1a plus 88 days after this stage in treatment $2 b$, when the maximum mortality was registered). Also, the metatrochophore stage lasted from a few hours to one day in the Italian population, and the length of the brooding females in the English population was 23 to $50 \mathrm{~mm}$, while in Capitella $\mathrm{sp}$. A the metatrochophore stage can last for four days and the average female length is $12.94 \mathrm{~mm}$. 
Table 3. - Differences between Capitella sp. A and the other lecithotrophic species studied around the world (M, metatrochophores; references in text).

\begin{tabular}{|c|c|c|c|c|c|c|c|}
\hline Capitella species & Locality & $\begin{array}{l}\text { Female size } \\
(\mathrm{mm})\end{array}$ & $\begin{array}{l}\text { M size } \\
(\mathrm{mm})\end{array}$ & $\begin{array}{l}\text { M duration } \\
\text { (days) }\end{array}$ & Ciliated M & Hermaphrodites & $\begin{array}{l}\text { Survival } \\
\text { (months) }\end{array}$ \\
\hline Capitella sp. A & Casas d'Alcanar & $11.1-15.6$ & $0.39-0.56$ & $1-4$ & yes & no & 5.6 \\
\hline Capitella sp. I & USA, Japan & & & & & yes & \\
\hline Capitella sp. IIIa & USA & & & & & yes & \\
\hline Capitella sp. Y & Mazatlán & & & & & yes & \\
\hline Capitella type 1 & West Scotland & $8-25$ & $1.14-3.45$ & & & no & \\
\hline Capitella sp. & Vancouver & & & 1 & & no & \\
\hline C. cf. capitata & Elba & & & $<1$ & & no & 9 \\
\hline C. capitata & Plymouth & $23-50$ & & & & no & 12 \\
\hline C. capitata & Barcelona & & & & no & & \\
\hline
\end{tabular}

The metatrochophores of a population of C. capitata from Barcelona observed inside the brood tubes measured about $0.44 \mathrm{~mm}$ (Méndez 1995), which matches the larval length of Capitella sp. A. However, the metatrochophores from Barcelona lacked ciliary rings, which were present in Capitella sp. A larvae (personal observations). Another species from Barcelona, Capitella $\mathrm{sp}$. B, has the ability to hatch trochophore and metatrochophore larvae non-simultaneously from single brood tubes, indicating that it is a poecilogonic species (Méndez 2002), which definitively is not the case of Capitella sp. A.

Developmental stages are among the main factors affecting growth in Capitella spp. (Linke-Gamenick et al. 2000), and Capitella sp. A is no exception, since juvenile growth was more affected than adult growth by scarcity of food. The growth of members of the Capitella species complex depends strongly on environmental food availability (Tenore 1977, Tsutsumi et al. 1990, Linton and Taghun 2000), as confirmed here by the results of experimental series 1. Accordingly, the juveniles and immature adults reared in the organic-enriched sediment (treatment 1a) had positive growth rates, whereas they were negative in juveniles from the natural sediment (treatment $1 \mathrm{~b}$ ). In addition, transparent and yellowish juveniles with three, four (experimental series 1) and five (experimental series 2) chaetigers with capillaries reared in the organic enriched sediment (treatments $1 \mathrm{a}$ and $2 a)$ had greater volumes than their respective stages reared in the natural (treatment 1b) and non-enriched sediment (treatment $2 \mathrm{~b}$ ) ones, respectively. Growth in Capitella sp. slows down when food becomes limited (Qian and Chia 1992), as happened with the juveniles in treatment $1 \mathrm{~b}$, who reached the various developmental stages later than those in treatment 1a. Moreover, maturity in worms exposed to the nonenriched treatment (2b) was delayed in comparison with those in the organic enriched treatment (2a) of the experimental series 2 (34 vs. 15 days on average, respectively).

Juveniles reared in the non-enriched treatment (1b and $2 \mathrm{~b}$ ) died at an earlier stage of development than those in enriched treatments (1a and 2a). Also, a high juvenile mortality due to lack of food occurred, as in Capitella sp. B, which did not reach the adult stage when reared in natural sediments (Méndez 2002).

The reduced size of genital spines of the three Capitella sp. A males reared in non-enriched treatment 2b may be attributable to the lack of food. Such small genital spines could have important reproductive disadvantages, as they may not be strong enough to hold females during mating.

Previous to experimental settings, sediment handling for the selection of experimental individuals from the stock cultures revealed the absence of brooding females inside their tubes, which only contained some broods with developing embryos inside. This led us to design experimental series 1 , in which couples were placed in dishes to allow fecundation and the subsequent production of brooding tubes. This lack of brooding females in the stock cultures has never been observed in other Capitella species maintained in laboratory cultures by Méndez et al. (2000) with five Capitella species, Méndez (2002) with Capitella sp. B or Méndez (2006) with Capitella sp. Y. Perhaps Capitella sp. A brooding females suffer stress during sediment handling, causing them to abandon the brood tube.

This study provides the first detailed observations on the reproductive biology of Capitella sp. A. The clear and consistent differences in developmental modes and reproductive structures of Capitella sp. A allow us to conclude that it does not belong to any of the known $C$. capitata sibling species worldwide. Despite its conclusive character, this study does not provide enough data to formally describe the species as a new one. Molecular techniques and fine morphological analyses could provide further evidences and this will certainly be an interesting approach for future studies. Finally, detailed evidence is also provided on the influence of the different levels of organic matter on growth, timing, survival and morphology in this species, key information that will be essential for any further ecological study and for the design of experiments with live worms of Capitella sp. A.

\section{ACKNOWLEDGEMENTS}

This study was performed in the Department of Environmental Chemistry Institute of Environmental Assessment and Water Research (CSIC), Barcelona under the direction of Carlos Barata and was supported by the Dirección General de Apoyo al Personal Académico, UNAM, Mexico. Jordi Flos, Agustí Montserrat and Agustí Cruelles helped during worm collection. Thanks also to Ann Grant and two anonymous referees for revising the final manuscript. 


\section{REFERENCES}

Adkins M., Schulze A. 2011. Development of Capitella sp. G from Galveston Bay, Texas. Mar. Biol. Res. 7: 202-207. http://dx.doi.org/10.1080/17451000.2010.489612

Blake J.A., Grassle J.P., Eckelbarger K.J. 2009. Capitella teleta, a new species designation for the opportunistic and experimental Capitella sp. I, with a review of the literature for confirmed records. Zoosymposia 2: 25-53.

Brown J.R., Gowen R.J., McLusky D.S. 1987. The effect of salmon farming on the benthos of a Scottish sea loch. J. Exp. Mar. Biol. Ecol. 109: 39-51. http://dx.doi.org/10.1016/0022-0981(87)90184-5

Eckelbarger K.J., Grassle J.P. 1983. Ultrastructural differences in the eggs and ovarian follicle cells of Capitella (Polychaeta) sibling species. Biol. Bull. 165: 379-393. http://dx.doi.org/10.2307/1541203

Forbes T.L., Lopez G.R. 1990. The effect of food concentration, body size, and environmental oxygen tension on the growth of the deposit-feeding polychaete, Capitella capitata species 1. Limnol. Oceanogr. 35: 1535-1544. http://dx.doi.org/10.4319/1o.1990.35.7.1535

Forbes T.L., Forbes V.E., Depledge M.H. 1994. Individual physiological responses to environmental hypoxia and organic enrichment: implications for early soft-bottom community succession. J. Mar. Res. 52: 1081-1100. http://dx.doi.org/10.1357/0022240943076849

Gamenick I. 1997. Ökophysiologische und enzymatische Differenzierung verschiedener Geschwisterarten des Capitella capitata - Komplexes (Annelida, Polychaeta). PhD thesis. Faculty of Biology. University of Hamburg, $112 \mathrm{pp}$.

Gamenick I., Abbiati M., Giere O. 1998. Field distribution and sulphide tolerance of Capitella capitata (Annelida: Polychaeta) around shallow water hydrothermal vents off Milos (Aegean Sea). A new sibling species? Mar. Biol. 130: 447-453. http://dx.doi.org/10.1007/s002270050265

George J.D. 1984. The behaviour and life history of a mangrovedwelling capitellid (Polychaeta). In: Hutchings P.A. (ed) Proceedings of the First International Polychaete Conference. Sydney Australia, Milsons Point: The Linnean Society of New South Wales. pp. 323-337.

Grassle J.P., Grassle J.F. 1976. Sibling species in the marine pollution indicator Capitella (Polychaeta). Science 192: 567-569. http://dx.doi.org/10.1126/science.1257794

Hermans C.O. 1979. Polychaete egg sizes, life histories and phylogeny. In: Stancyk S.E. (ed), Reproductive Ecology of Marine Invertebrates, Columbia. University of South Carolina Press, pp. 1-9.

Lardicci C., Ceccherelli G. 1994. Dinamica di popolazione di una specie del complesso Capitella capitata in un piccolo bacino salmastro dell' isola d'Elba. Biol. Mar. Medit. 1: 355-356.

Linke-Gamenick I., Forbes V.E., Méndez N. 2000. Effects of chronic fluoranthene exposure on sibling species of Capitella with different development modes. Mar. Ecol. Progr. Ser. 203: 191-203. http://dx.doi.org/10.3354/meps203191

Linton D.L., Taghun G.L. 2000. Feeding, growth, and fecundity of Capitella sp. I in relation to sediment organic concentration. Mar. Ecol. Progr. Ser. 205: 229-240. http://dx.doi.org/10.3354/meps205229

Méndez N. 1995. Non-pelagic development of Capitella capitata (Polychaeta) in the littoral zone of Barcelona, Spain. Sci. Mar. 59: 95-101.

Méndez N. 2002. Experimental evidence of polymorphysm of sexual development in Capitella sp B (Polychaeta: Capitellidae) from Barcelona, Spain. Sci. Mar. 66: 103-110. http://dx.doi.org/10.3989/scimar.2002.66n2103

Méndez N. 2006. Life cycle of Capitella sp Y (Polychaeta: Capitellidae) from Estero del Yugo, Mazatlan, Mexico. J. Mar. Biol. Ass. U.K. 86: 263-269.

http://dx.doi.org/10.1017/S0025315406013117
Méndez N., Barata C. 2015. Effects of the antidepressant fluoxetine in spiked-sediments on developmental and reproductive features of the polychaetes Capitella teleta and Capitella sp A. Ecotoxicology 24: 106-118. http://dx.doi.org/10.1007/s10646-014-1362-z

Méndez N., Romero J., Flos J. 1997. Population dynamics and production of the polychaete Capitella capitata in the littoral zone of Barcelona (Spain, NW Mediterranean). J. Exp. Mar. Biol. Ecol. 218: 263-284. http://dx.doi.org/10.1016/S0022-0981(97)00078-6

Méndez N., Flos J., Romero J. 1998. Littoral soft-bottom polychaete communities in a pollution gradient in front of Barcelona (Western Mediterranean, Spain). Bull. Mar. Sci. 63: 167-178.

Méndez N., Linke-Gamenick I., Forbes V.E. 2000. Variability in reproductive mode and larval development within the Capitella capitata species-complex. Invetebr. Reprod. Dev. 38: 131-142. http://dx.doi.org/10.1080/07924259.2000.9652448

Pearson M., Pearson T.H. 1991. Variation in populations of Capitella capitata (Fabricius, 1780) (Polychaeta) from the West coast of Scotland. Ophelia Suppl. 5: 363-370.

Pearson T.H., Rosenberg R. 1978. Macrobenthic succession in relation to organic enrichment and pollution of the marine environment. Oceanogr. Mar. Biol. Ann. Rev. 16: 229-311.

Pechenik J.A., Cerulli T.R. 1991. Influence of delayed metamorphosis on survival, growth, and reproduction of the marine polychaete Capitella sp I. J. Exp. Mar. Biol. Ecol. 151: 17-27. http://dx.doi.org/10.1016/0022-0981(91)90012-L

Petraitis P.S. 1985. Females inhibit males' propensity to develop into simultaneous hermaphrodites in Capitella species I (Polychaeta). Biol. Bull. Mar. Biol. Lab. Woods Hole. 168: 395-402. http://dx.doi.org/10.2307/1541520

Qian P., Chia F.S. 1992. Effects of diet type on the demographics of Capitella capitata (Annelida: Polychaeta): Lecithotrophic development vs planktotrophic development. J. Exp. Mar. Biol. Ecol. 157: 159-179 http://dx.doi.org/10.1016/0022-0981(92)90160-C

Qian P., Chia F.S. 1994. In situ measurement of recruitment, mortality, growth, and fecundity of Capitella sp. (Annelida: Polychaeta). Mar. Ecol. Progr. Ser. 111: 53-62. http://dx.doi.org/10.3354/meps 111053

Reish D.J. 1980. Use of polychaetous annelids as test organisms bioassay experiments. In: Buikema A.L. Jr, Cairns J. Jr. (eds), Aquatic Invertebrate Bioassays, ASTM STP 715, American Society for Testing and Materials. pp. 140-154. http://dx.doi.org/10.1520/STP33413S

Tenore K.R. 1977. Growth of Capitella capitata cultured in various levels of detritus from different sources. Limnol. Oceanogr. 22: 936-941. http://dx.doi.org/10.4319/1o.1977.22.5.0936

Tsutsumi H. 1987. Population dynamics of Capitella capitata (Polychaeta: Capitellidae) in an organically polluted cove. Mar. Ecol. Prog. Ser. 36: 139-149. http://dx.doi.org/10.3354/meps036139

Tsutsumi H., Kikuchi T. 1984. Study of the life history of Capitella capitata (Polychaeta: Capitellidae) in Amakusa, South Japan, including a comparison with other geographical regions. Mar. Biol. 80: 315-321. http://dx.doi.org/10.1007/BF00392827

Tsutsumi H., Fukunaga S., Fujita N., et al. 1990. Relationship between growth of Capitella sp. and organic enrichment of the sediment. Mar. Ecol. Progr. Ser. 63: 157-162. http://dx.doi.org/10.3354/meps063157

Warren L.M. 1976a. A population study of the polychaete Capitella capitata in Plymouth. Mar. Biol. 38: 209-216. http://dx.doi.org/10.1007/BF00388934

Warren L.M. 1976b. A review of the genus Capitella (Polychaeta, Capitellidae). J. Zool. 180: 195-209. http://dx.doi.org/10.1111/j.1469-7998.1976.tb04673.x

Wu B.L., Qian P.Y., Zhang S.L. 1991. Morphology, Reproduction, Ecology and allozyme electrophoresis of three Capitella sibling species in Qingdao (Polychaeta: Capitellidae). Ophelia Suppl. 5: 391-400. 